\title{
Impact and effectiveness of meningococcal vaccines: a review
}

\author{
Lucia Helena De Oliveira, ${ }^{1}$ Barbara Jauregui, ${ }^{1}$ Ana Flavia Carvalho, ${ }^{2}$ and \\ Norberto Giglio ${ }^{3}$
}

Suggested citation

De Oliveira LH, Jauregui B, Carvalho AF, Giglio N. Impact and effectiveness of meningococcal vaccines: a review. Rev Panam Salud Publica. 2017;41:e158. doi: 10.26633/RPSP.2017.158

ABSTRACT Objectives. To summarize and critically evaluate the evidence on the impact and effectiveness of meningococcal vaccination programs around the world in order to inform decisionmaking in Latin America and the Caribbean.

Methods. A review of the literature was conducted following several components of the Preferred Reporting Items for Systematic Reviews and Meta-Analyses guidelines. PubMed Central ${ }^{\circledR}$ was searched for papers published in any language from January 1999 - March 2017. Results. In all, 32 studies were included, most of which evaluated the meningococcal C conjugate vaccine. Fourteen studies measured effectiveness and 30 measured impact. The effectiveness of polysaccharide vaccines was $65 \%-83.7 \%$ (different age groups), while the effectiveness of the conjugate vaccines was $66 \%$ - 100\%. Incidence decline of laboratory-confirmed meningococcal disease for the conjugate vaccine ranged from $77 \%$ - 100\% among different ages groups. The only study that evaluated the protein subunit vaccine reported a vaccine effectiveness of $82.9 \%$.

Conclusions. The studies reviewed show impact and effectiveness of both polysaccharide vaccines and conjugate vaccines on vaccine-serogroup meningococcal disease. The conjugate vaccines, however, show higher impact and effectiveness with longer-lasting protection over the polysaccharide vaccines. Given the variance in potential use of a meningococcal vaccine, epidemiological surveillance systems should be strengthened to inform national decisions.

Keywords Meningococcal vaccines; immunization programs; decision making, prevention \& control; review; Latin America.

Meningococcal disease is a global problem that occurs in all countries, but its epidemiology varies substantially by capsular group (1). Virulent strains of Neisseria

\footnotetext{
Comprehensive Family Immunization Unit, Pan American Health Organization, Regional Office of the World Health Organization, Washington, DC, United States of America. Send correspondence to Lucia Helena De Oliveira, oliveirl@paho.org

2 Albert B. Sabin Vaccine Institute, Washington, DC, United States.

3 Hospital Gutierrez, Buenos Aires, Argentina.
}

Meningitidis have a polysaccharide capsule, with types A, B, C, W, X, and Y commonly causing invasive infections (2).

The incidence of invasive meningococcal disease (IMD) is highest in children less than 1 year of age and remains relatively high until approximately 5 years. Although the incidence tends to decrease in older children, it usually peaks again during adolescence and young adulthood when individuals are living in close quarters. Incidence again tapers off in older adults. This pattern has been observed at both regional and country levels and with individual serogroups. The morbidity and mortality from IMD is substantial, with a casefatality rate close to $10 \%$ in developed countries (3). Many survivors experience permanent debilitating sequelae, such as hearing loss, neurologic impairments, or limb loss (4). 
The development of meningococcal vaccines began in the 1960s with the creation of the polysaccharide vaccines, which are immunogenic in older children and adults, but less so in infants. To cover this younger population, conjugate vaccines were developed in 1999. Polysaccharide vaccines and conjugate vaccines based on the meningococcal capsule are now available against all meningococcal strains related to serogroups A, C, W, and Y. Regarding protection against serogroup B, a broadly protective serogroup $B$ recombinant vaccine has recently been approved in several countries $(5,6)$.

According to the World Health Organization's (WHO) Vaccine Preventable Diseases Monitoring System, as of 2016, a total of 39 countries had introduced a meningococcal vaccine in their routine immunization schedules. The first country to introduce the conjugate vaccine was the United Kingdom in 1999. Additionally, 30 countries have introduced a meningococcal vaccine for specific highrisk groups only. Infants and young children less than 2 years of age are targeted in 27 countries, while nine countries target children 2 years of age or older and 11 countries target adolescents. Only five countries have introduced a meningococcal vaccine in a geographically restricted area within the country, while the rest have introduced it nationwide $(7,8)$.

Some countries in Latin America and the Caribbean have decided to implement a nationwide, routine immunization program using meningococcal vaccines. Brazil was the first to introduce a conjugated meningococcal $C$ vaccine (MenC), while Cuba was the first to introduce an outer-membrane protein B vaccine (9). Afterwards, Puerto Rico and Chile introduced the ACWY tetravalent polysaccharide-protein conjugate vaccines in 2008 and 2012, respectively; Argentina did likewise in $2017(10,11)$.

Monitoring post-licensure impact of meningococcal vaccines is important for documenting appropriate gains in terms of expected morbidity and mortality reduction. This information is scarce and scattered in Latin America and the Caribbean, making it difficult for decisionmakers to base policy on evidence. This review aims to summarize the available evidence on the impact and effectiveness of commercially-available vaccines on meningococcal disease, invasive meningococcal disease, and death due to meningococcus in all age groups, as reported by several countries. The intent is inform decision making among countries of Latin America and the Caribbean that are considering introducing the meningococcal vaccine.

\section{MATERIALS AND METHODS}

\section{Literature search}

A literature search following several components of the Preferred Reporting Items for Systematic Reviews and Meta-Analyses (PRISMA) guidelines ${ }^{4}$ was performed on PubMed Central ${ }^{\circledR}(\mathrm{Na}-$ tional Library of Medicine, Bethesda, Maryland, United States) to identify all available studies on the effects of meningococcal vaccines on meningococcal disease cases and mortality. The main search terms were: "meningococcal vaccine," "immunization program," "mass vaccination," AND "effectiveness" OR "evaluation" OR "impact" OR "benefits," "hospitalization," "notifications," "decline" OR "reduction." Terms used for exclusion of papers were: "meningococcal vaccines/economics" OR "immuniza tion/economics" or "cost-benefit analysis" OR "MenAfriVac" OR “disease outbreaks" OR "randomized controlled trial." The search included all papers published from 1 January 1999 - 15 March 2017 , the day on which the search was conducted.

\section{Inclusion and exclusion criteria}

Studies of primary impact and effectiveness of currently available meningococcal vaccines were included, published from January 1999 - March 2017, in any language. The review focused on the meningococcal polysaccharide, polysaccharide-protein conjugate, and protein sub unit vaccines, and considered any serogroup except for serogroup A. The outcomes of interest were clinically-compatible and/or laboratory-confirmed meningococcal cases and deaths due to meningococcal disease.

The following study types were excluded: case series, case reports, and randomized controlled trials; and economic, cost-benefit, and modelling studies.

\footnotetext{
${ }^{4}$ An evidence-based minimum set of items for reporting in systematic reviews and meta-analyses, focusing on the reporting of reviews evaluating randomized trials, but also used as a basis for reporting systematic reviews of other types of research, particularly evaluations of interventions. For more information visit: www.prisma-statement.org/
}

Additionally, studies performed in Africa related to meningococcal A vaccine were excluded for not being relevant to Latin American and the Caribbean, as were those studies specifically targeting patients with sickle cell disease, HIVinfection, or conditions known to affect immune response. Others excluded were: studies that considered only the disease of selected serogroups without denominators, adverse events, or immunogenicity (antibody levels); studies of nasopharyngeal carriage; studies considering only laboratory data; studies with all-cause mortality and hospitalization as primary outcomes; and studies that assessed only nosocomial infections.

\section{Study selection}

Citations were screened by two independent reviewers in a two-step process. First, titles and abstracts were reviewed for duplication and inclusion/exclusion criteria. After eliminating duplicates, the full texts of these papers were obtained to complete the eligibility screening. Second, five citations on which eligibility reviewers disagreed were discussed or assessed by a third reviewer.

By screening the abstracts of the remaining 209 studies, 158 were excluded-30 were not related to meningococcal vaccine; 95 did not measure vaccine impact; 6 were reviews (not primary studies); 3 were reports or press release; 8 were studies of meningococcal A vaccine; 3 were studies of vaccines that are not commercially available; and 13 were modelling/economic evaluations.

The full texts of 51 studies were then evaluated, and another 19 were excluded, resulting in 32 primary studies for this review $(12-43)$. Figure 1 shows the PRISMA Flow Diagram of the search strategy and selected articles.

\section{Data collection and study quality}

Data extraction was done independently by three reviewers, using abstraction forms developed specifically for this review. Data extracted included first author, country and state when available, vaccine and serogroup type, study type, data source, study period, vaccine introduction date, vaccination strategy, vaccination schedule used, age groups on which impact was measured, number of subjects on which impact was measured, case definition, effectiveness, or impact 
FIGURE 1. PRISMA Flow Diagram for selection of articles for a review of the literature on the impact and/or effectiveness of meningococcal vaccines, 2016

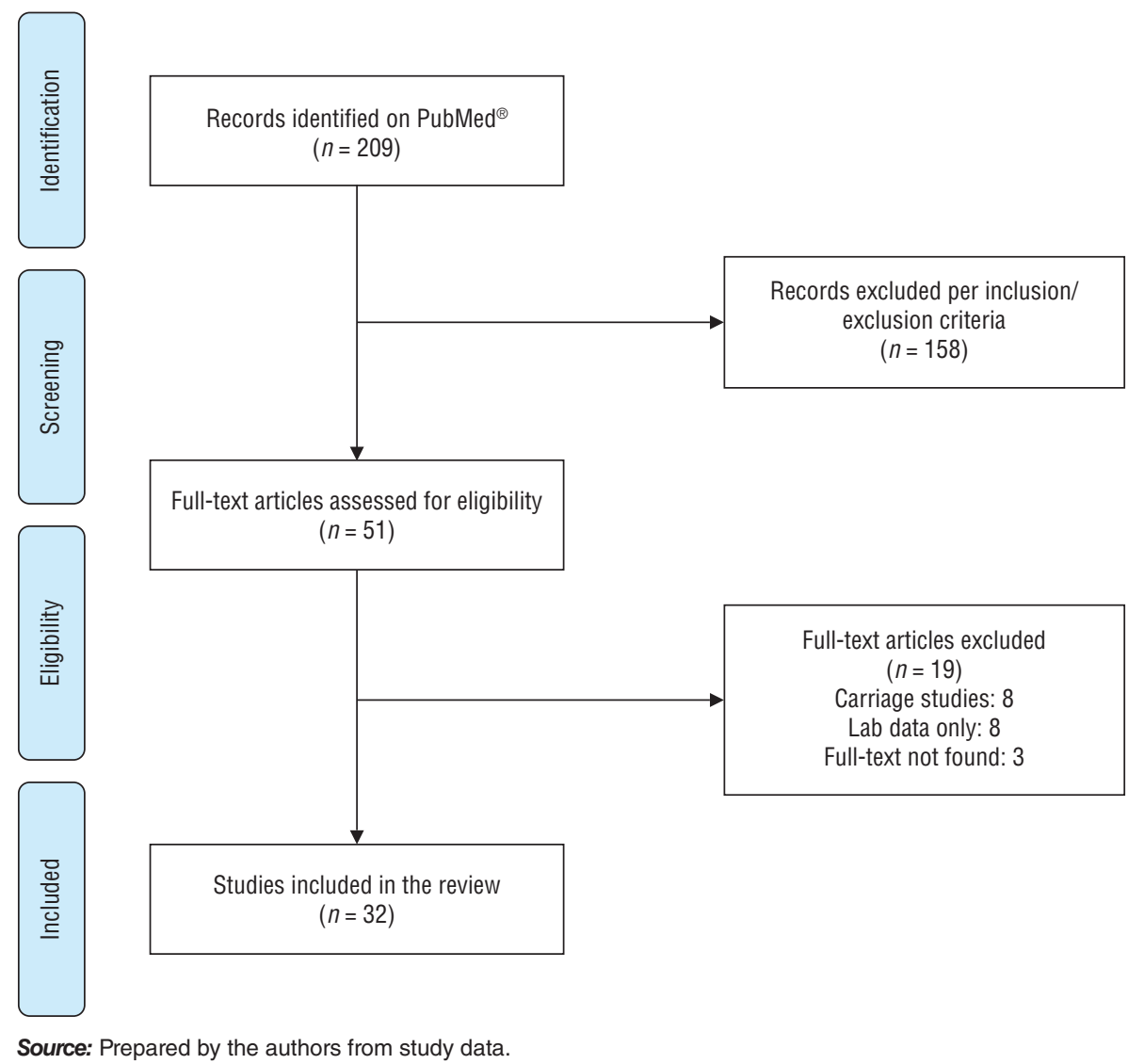

as reported, and main conclusion of the study.

The main results included were impact and/or effectiveness assessments, corresponding confidence limits when available, and any information on control and ascertainment of exposure for casecontrol studies and cohort studies. Additionally, control (as steady practice) and presence of time series before were evaluated for impact studies.

\section{Data analysis}

A descriptive analysis was conducted of each study's characteristics including design, type, and schedule of meningococcal vaccine introduced, vaccination strategy, data sources, and endpoints considered. For all studies, the main measure of interest was the vaccine effect in reducing the outcome of interest.

\section{RESULTS}

Table 1 summarizes the characteristics of the 32 articles selected. Most of them were spread out evenly through the study period. Of the total, 26 evaluated conjugate vaccines $(12-37)$ and 6 evaluated polysaccharide vaccines $(38-43)$. By far, the vaccine most commonly evaluated was the meningococcal conjugate C vaccine (Men-C-C), with 25 articles; some studies evaluated multiple vaccines. The studies originated from several countries, with Spain being the most prolific publisher (10 studies), followed by Canada (8 studies). The study periods of the 32 selected articles ranged from 1 - 58 years, with an average of 8.7 years and a median of 5 years. The most common data sources for the studies were surveillance systems (27 studies).

Regarding the immunization strategy, most countries studied had introduced a meningococcal vaccine to their routine immunization program (25 studies) and 4 had also conducted catch-up for older age groups. Eleven studies evaluated the use of a meningococcal vaccine in a campaign. The vaccination schedule used varied widely. In September 2015, the United Kingdom became the first country to introduce meningococcal vaccine $(4 \mathrm{CMenB})$, a protein sub-unit vaccine,
TABLE 1. Characteristics of the articles included in a review of the literature on the impact and/or effectiveness of meningococcal vaccines, 2016

\begin{tabular}{|c|c|c|}
\hline Characteristics & $n$ (Total 32) & $\%$ \\
\hline \multicolumn{3}{|l|}{ Publication year } \\
\hline 1999 & 1 & 3 \\
\hline 2000 & 1 & 3 \\
\hline 2001 & 3 & 9 \\
\hline 2002 & 0 & 0 \\
\hline 2003 & 3 & 9 \\
\hline 2004 & 4 & 13 \\
\hline 2005 & 2 & 6 \\
\hline 2006 & 0 & 0 \\
\hline 2007 & 0 & 0 \\
\hline 2008 & 1 & 3 \\
\hline 2009 & 2 & 6 \\
\hline 2010 & 0 & 0 \\
\hline 2011 & 2 & 6 \\
\hline 2012 & 2 & 6 \\
\hline 2013 & 0 & 0 \\
\hline 2014 & 5 & 16 \\
\hline 2015 & 2 & 6 \\
\hline 2016 & 4 & 13 \\
\hline \multicolumn{3}{|l|}{$\begin{array}{l}\text { Type of vaccine } \\
\text { (not mutually exclusive) }\end{array}$} \\
\hline Meningo Conjugate $\mathrm{C}$ & 25 & 78 \\
\hline Polysaccharide $A+C$ & 4 & 13 \\
\hline MenACWY-135 & 2 & 6 \\
\hline 4CMenB & 1 & 3 \\
\hline VA Meningo BC & 1 & 3 \\
\hline Polysaccharide MenC & 1 & 3 \\
\hline \multicolumn{3}{|l|}{ Country } \\
\hline Spain & 10 & 31 \\
\hline Canada & 8 & 25 \\
\hline United Kingdom & 4 & 13 \\
\hline Brazil & 3 & 9 \\
\hline Italy & 3 & 9 \\
\hline Australia & 1 & 3 \\
\hline Cuba & 1 & 3 \\
\hline Ireland & 1 & 3 \\
\hline Scotland & 1 & 3 \\
\hline \multicolumn{3}{|l|}{$\begin{array}{l}\text { Study type (not mutually } \\
\text { exclusive) }\end{array}$} \\
\hline Impact & 30 & 94 \\
\hline Effectiveness & 14 & 47 \\
\hline \multicolumn{3}{|l|}{ Data sources } \\
\hline Surveillance & 27 & 84 \\
\hline Hospital records & 5 & 16 \\
\hline
\end{tabular}

using a 2- and 4 months-old schedule with an opportunistic catch-up at 3 and 4 months of age. Among the 26 studies that looked at the conjugate meningococcal vaccines (12 - 37), 23 evaluated routine introductions to national schedules and 6 evaluated campaigns; just a few studies evaluated both. Regarding the routine introduction of conjugate vaccines, the 
most common schedule used was a single dose at $12-15$ months of age (11 studies), followed by a three-dose schedule of 2-, $4-$, and 6-months of age (6 studies). Four studies also vaccinated adolescents at around 12 years of age. Almost one-half of the conjugate vaccine schedules (12 articles) included a catch-up strategy for older age groups. Regarding the use of conjugate vaccines in campaigns, the targeted ages ranged from 2 months - 20 years of age.

The use of polysaccharides vaccines in the studies identified was predominantly during campaigns (4 of 6 studies), covering a wide range of age groups, usually including infancy - late adolescence. It is noteworthy that these studies were published in the 1990s (38-43).

Regarding the estimation of impact or effectiveness of the vaccines, approximately two-thirds of the studies (19 articles) evaluated the impact and/or effectiveness of the vaccine on the entire population, whereas the remaining onethird (13 articles) restricted the measure of effect to a certain age range or specific group. Meningococcal cases with lab confirmation (culture and/or cerebrospinal fluid polymerase chain reaction) were used as the most common endpoint included (25 studies) and secondary data from health information systems, surveillance systems, and other sources were also used. Seven studies evaluated laboratory-confirmed invasive meningococcal disease.

Fourteen studies measured effectiveness by comparing risk or rates in vaccinated and unvaccinated people during the same time period. Thirty studies measured impact by comparing a pre-vaccine introduction period to a post-vaccine introduction period. Regarding the degree of impact of meningococcal vaccines, onethird (11 studies) did not report a measure of change, but rather estimates before and after the introduction. Among the 21 studies that did report a specific measure of impact or change, the actual measure varied, with vaccine effectiveness being the most common measure (14 studies), followed by incidence decline (9 studies), and lastly, relative risk (2 studies). The age range on which the impact was measured also varied within and among studies. A summary of main outcomes and characteristics of the 32 studies included can be found in Tables $2 \mathrm{a}-\mathrm{d}$. Among the studies that estimated effectiveness of the polysaccharide vaccines, results ranged from $65 \%$ (Canada) $-83.7 \%$ (Spain). In the Canada study, vaccine effectiveness was not sustained beyond the second year of the study, showing no effectiveness in years $3-5$. The only other study that provided an impact estimate for the polysaccharide vaccines was the United Kingdom, reporting a relative risk of 0.94 .

With the studies that estimated the effect of the conjugate vaccines, effectiveness estimates ranged from $66 \%$ (United Kingdom) - 100\% (Spain), and the incidence decline ranged from $77 \%$ (Canada) $-100 \%$ (Spain). The only study that evaluated the protein sub-unit vaccine reported a vaccine effectiveness of $82.9 \%$.

\section{DISCUSSION}

Overall, the 32 studies included in this review showed a positive impact and effectiveness of both the polysaccharide vaccines and the conjugate vaccines on vaccine-serogroup meningococcal disease and mortality; but the conjugate vaccines show higher impact and effectiveness, plus longer lasting protection over the polysaccharide vaccines. Pelton and colleagues (3) reported similar results, including several studies that showed reductions in vaccine serogroup invasive meningococcal disease incidence after meningococcal polysaccharide vaccines or polysaccharide protein conjugate vaccine introduction, while the overall incidence of other serogroups remained stable, an effect observed in this review's studies as well. Nonetheless, it is important to consider the advantages of conjugate vaccines, which are well established in regards to immunologic memory and protection in the youngest children (less than 2 years of age) who respond poorly to polysaccharide vaccines. Also, the ability of conjugate vaccines to reduce carriage allows for significant indirect benefits through herd protection, reducing transmission of meningococci (44).

\section{Study limitations}

As mentioned above, this literature review selected effectiveness and impact studies of meningococcal vaccines. Vaccine effectiveness is a measure of protection attributable to a vaccine administered under field conditions to a given population and is measured by observational studies. In turn, impact of a vaccination program is measured by the fraction of prevented disease in a population and is estimated by comparing populations with and without vaccination, usually the same population before and after vaccination. The impact of a vaccination program refers to the program's overall effect. Different study designs are used for measuring effectiveness and impact, but all the post-licensure study designs present a certain level of bias. For example, in effectiveness studies, the level of natural protection against disease may differ between vaccinees and non-vaccinees, the target group for vaccination may have a higher probability of developing the disease, or the ascertainment of the disease may differ depending on vaccination status. On the other hand, impact studies could enable bias, such as secular trends in baseline transmission or cyclical variations of the target disease, changes in case detection or surveillance methods, or the presence of a concomitant intervention, such as prudent antibiotic use, which has an impact on the target disease as well (45). The majority of the studies included in this review are impact studies using mostly before-and-after design. A study-bystudy assessment of risk bias was not conducted and may represent a limitation to the interpretation of results.

Regarding the reported results, many of the studies did not report a measure of change; among those that did, their measures varied, as did the age range of their study participants. These variations make it difficult to draw comparisons between studies, and even harder to consolidate estimates in an attempt to obtain a "big picture" of the impact of meningococcal vaccines on disease and death due to meningococcus. Additionally, it is worth noting that the countries studied use different vaccine schedules, target a variety of age groups, implement primary vaccination with or without catch-ups, and apply diverse meningococcal disease diagnostic methods, all of which influence results and interpretation.

Of the 32 selected, there was only one study of the impact of the protein subunit vaccine serogroup B 4CMenB (35); this was in part because it was just licensed in 2015. The United Kingdom was the first country to introduce it to the national immunization program (46). During the program's first 10 months, the two-dose 4CMenB schedule has been highly effective in preventing meningococcal B (MenB) disease in infants. 


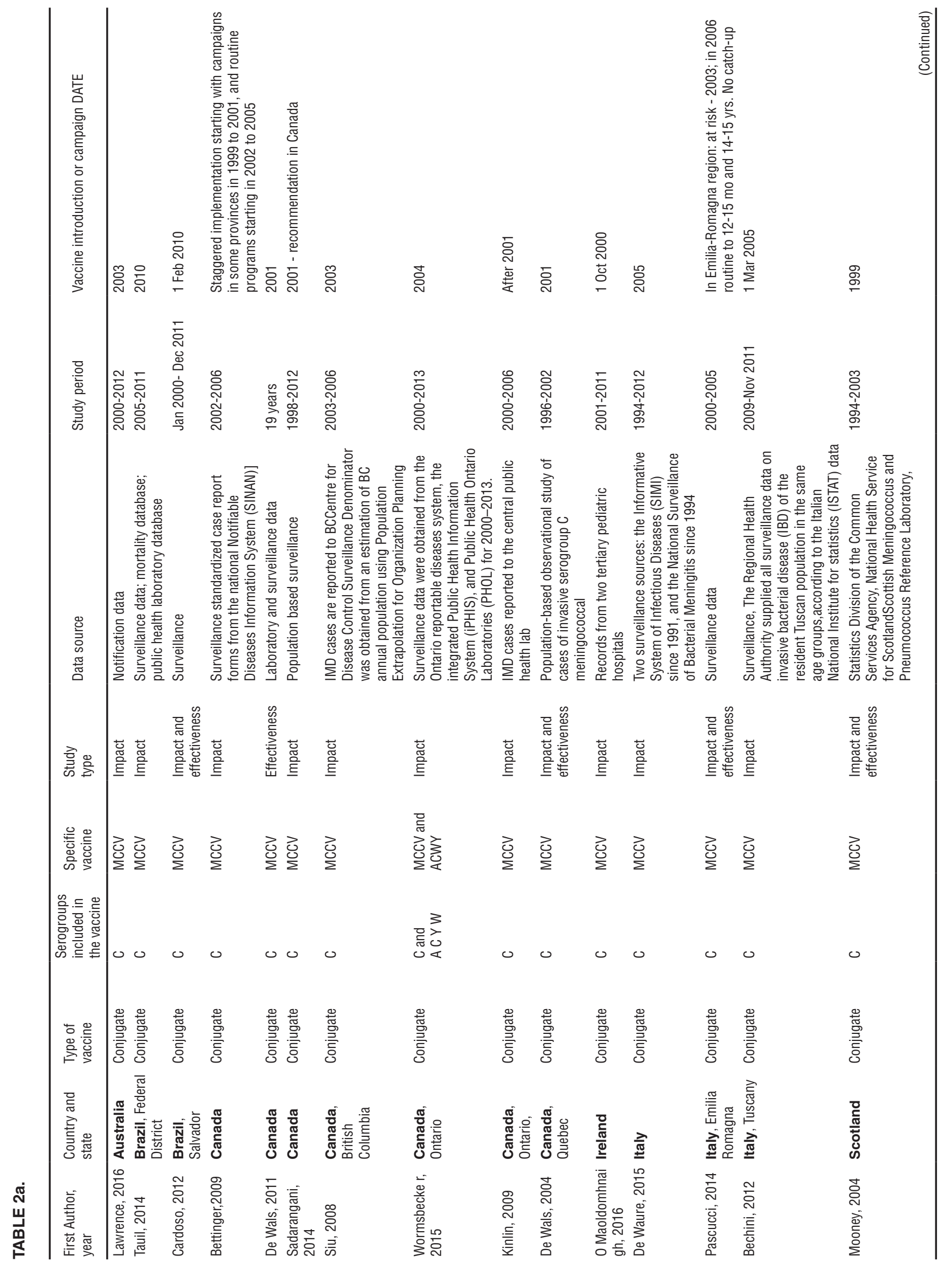




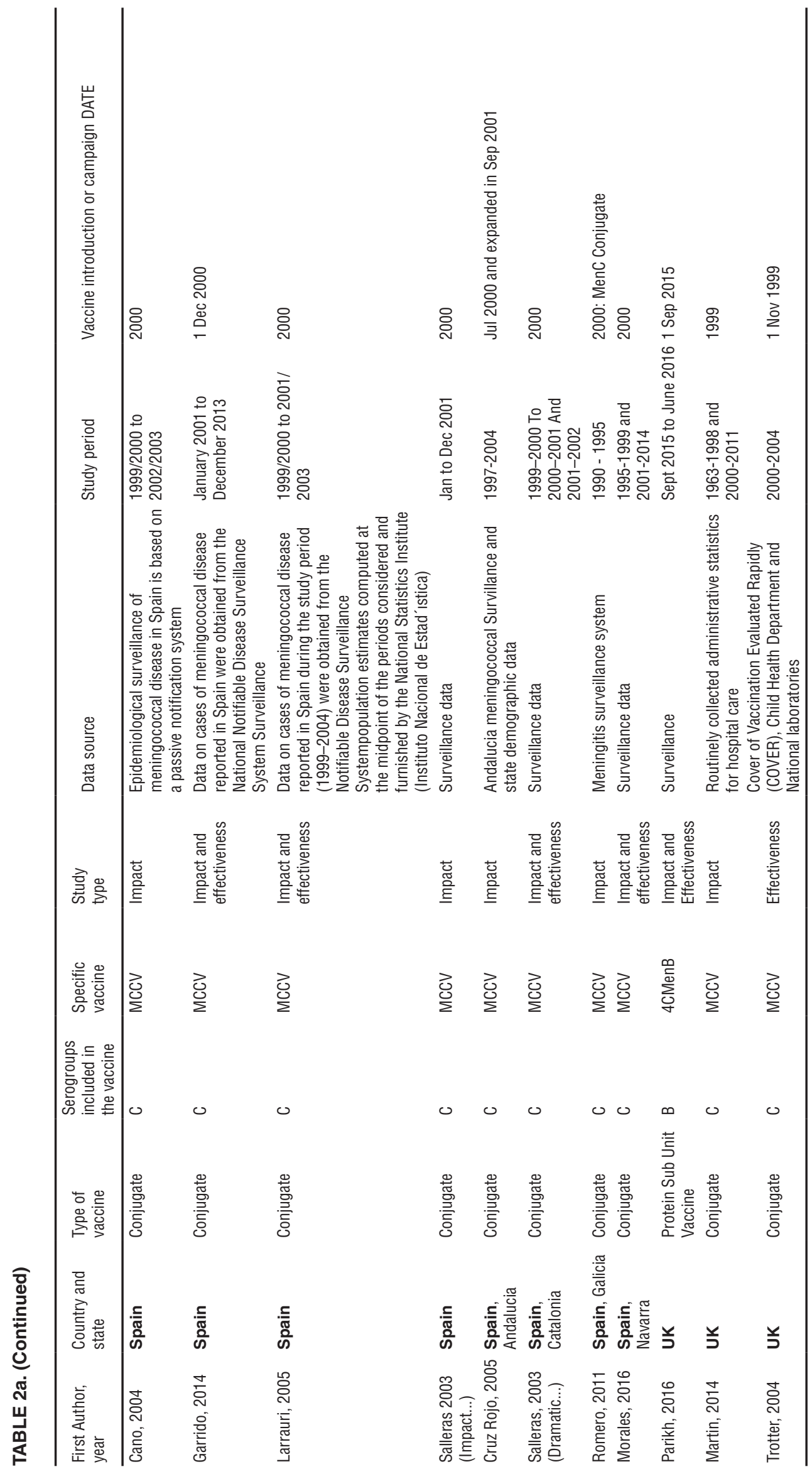




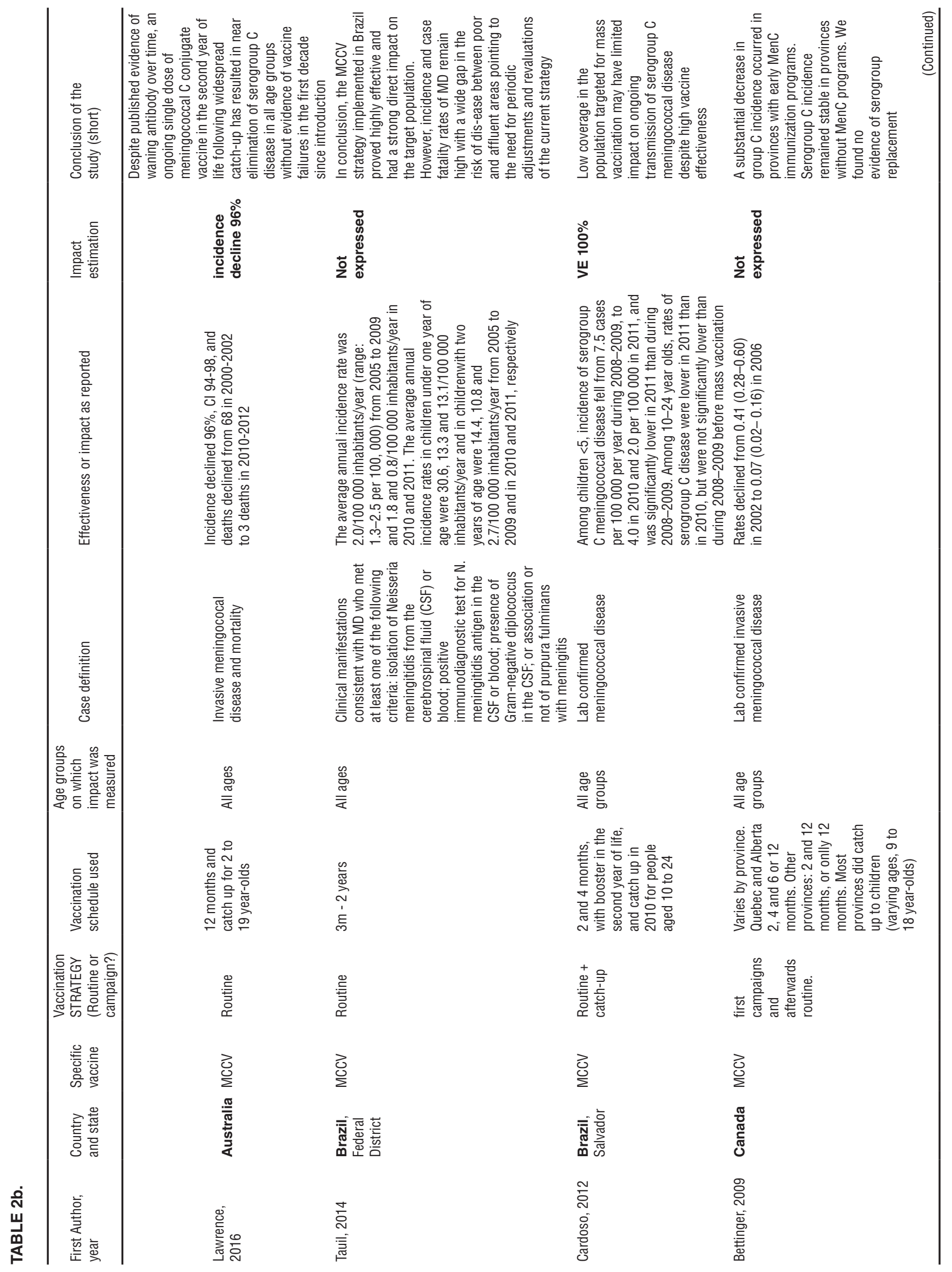




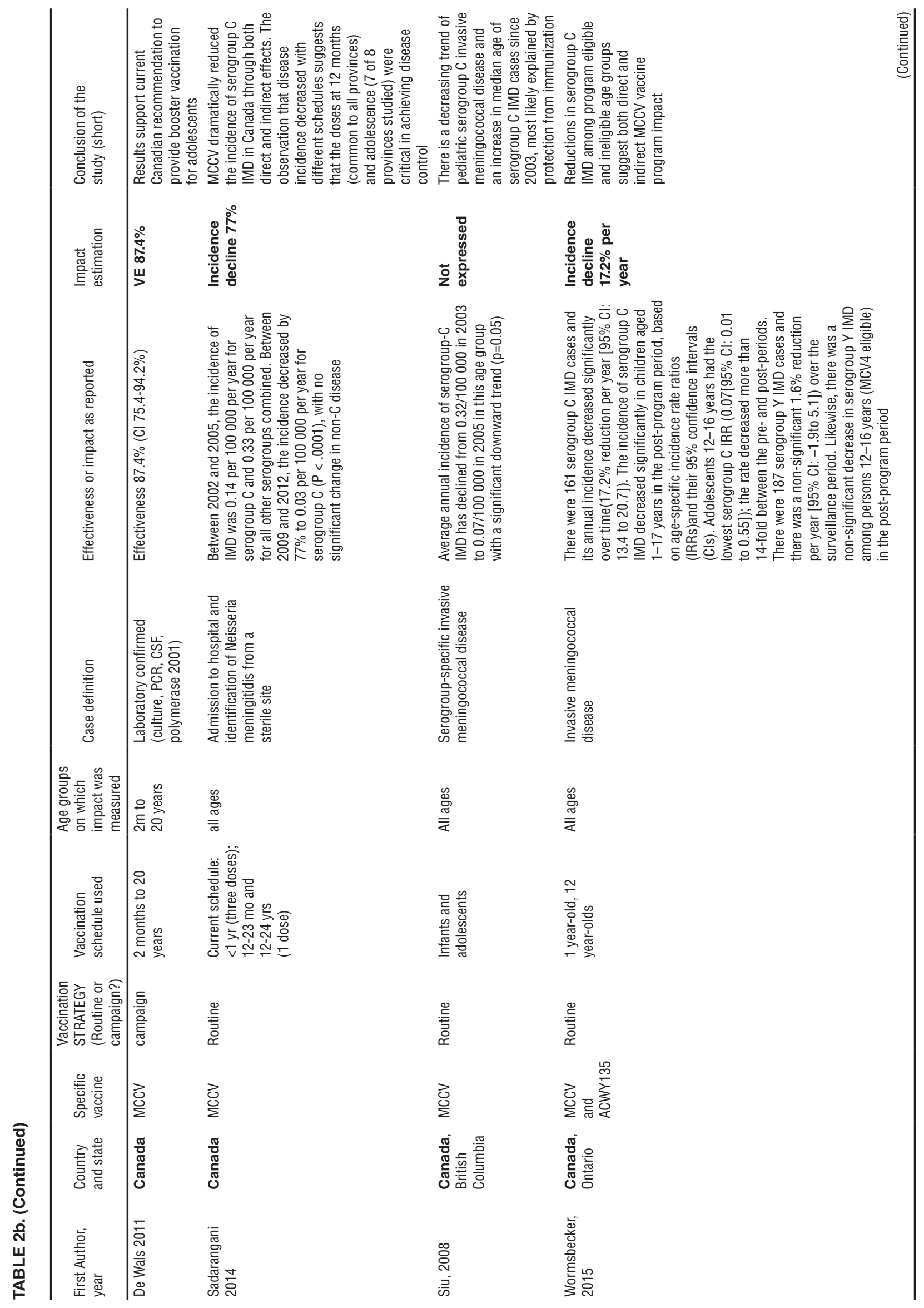




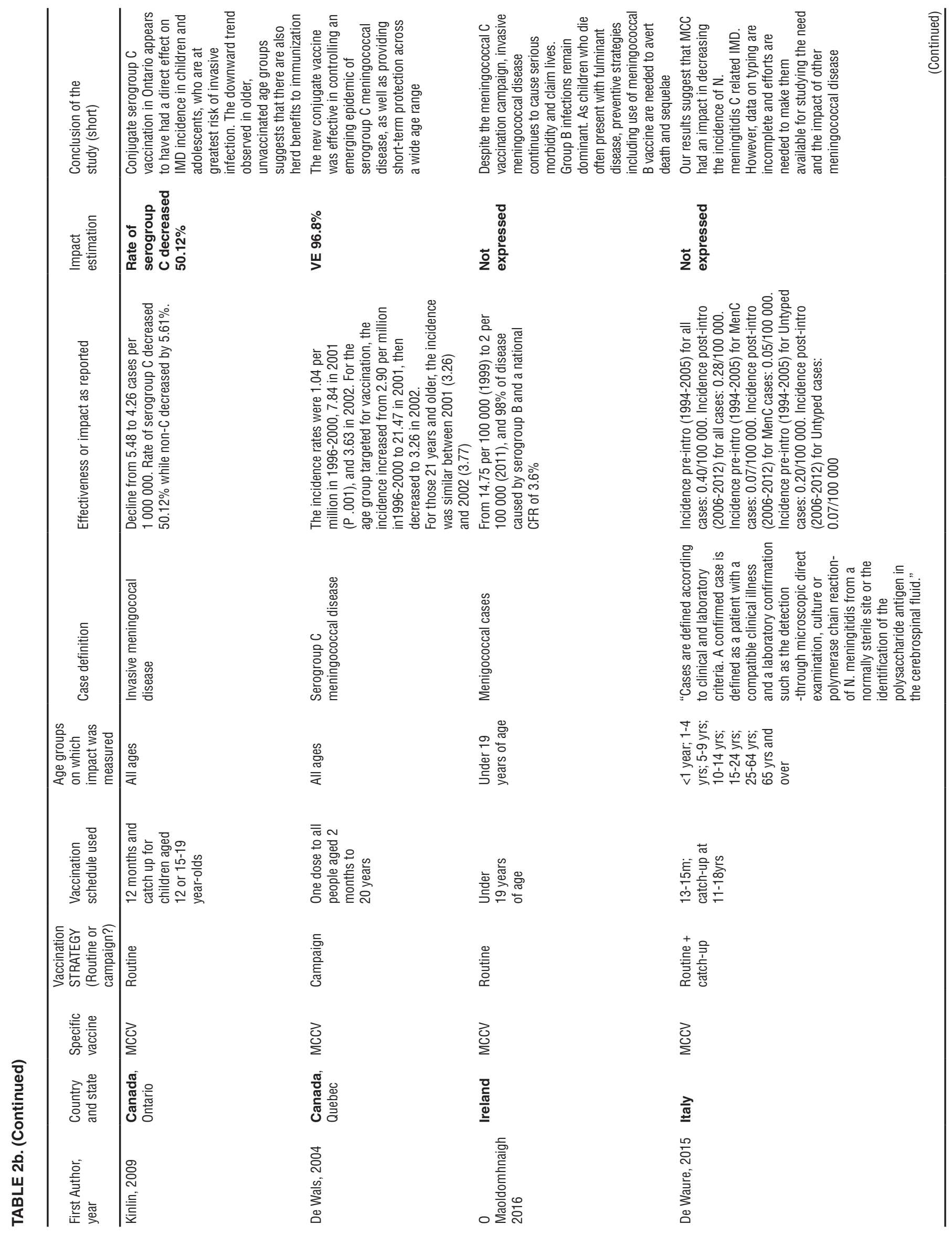




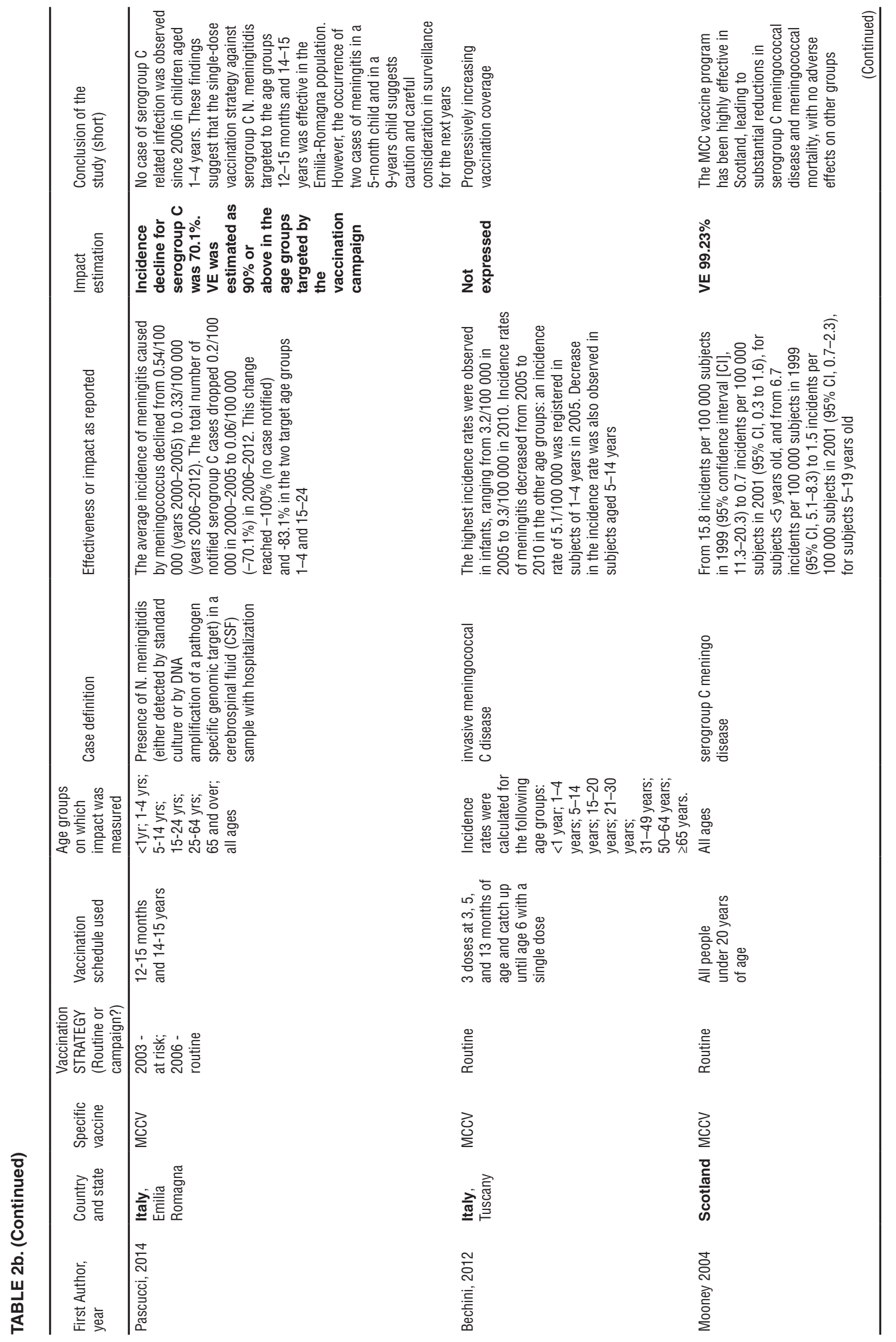




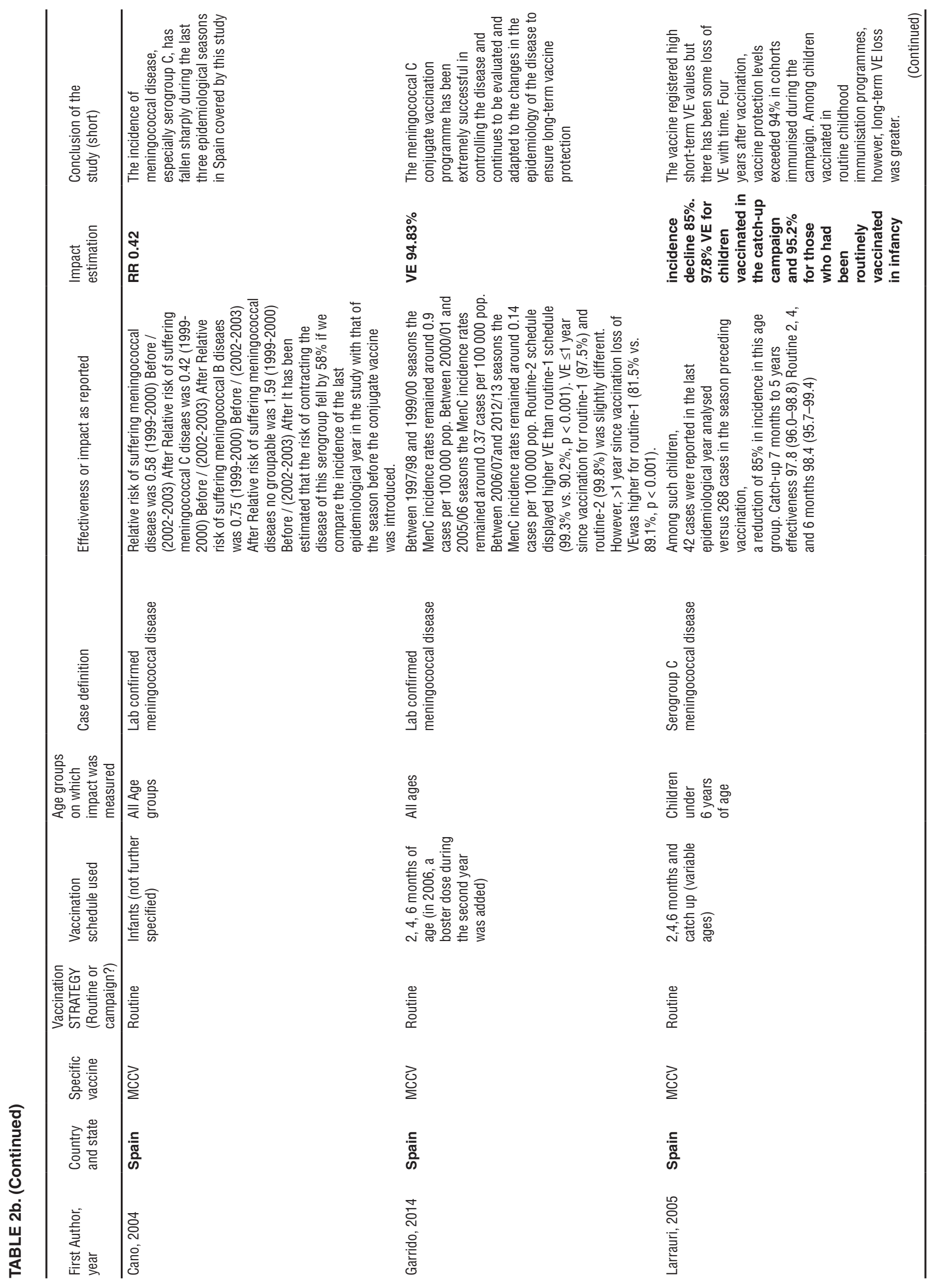




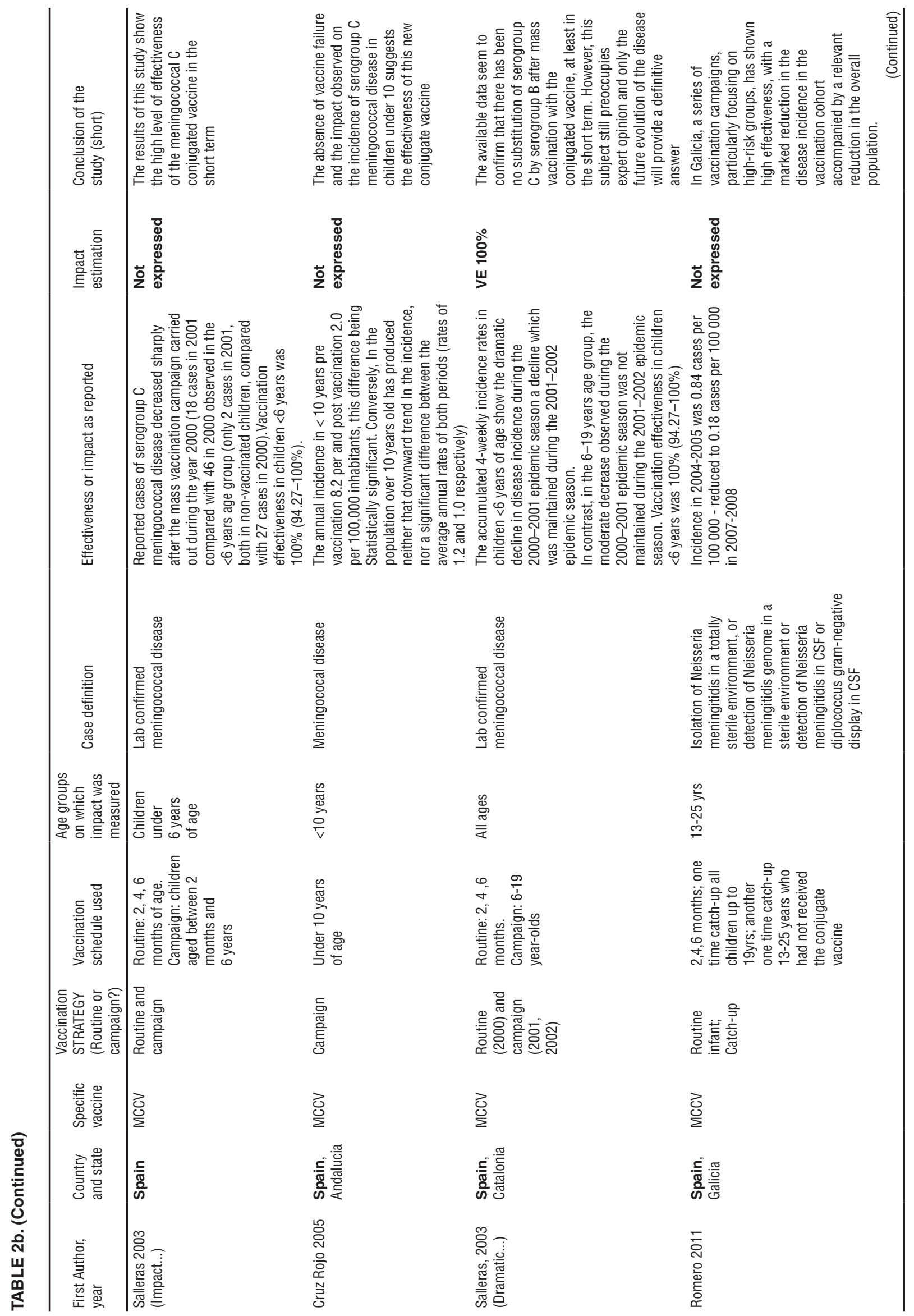




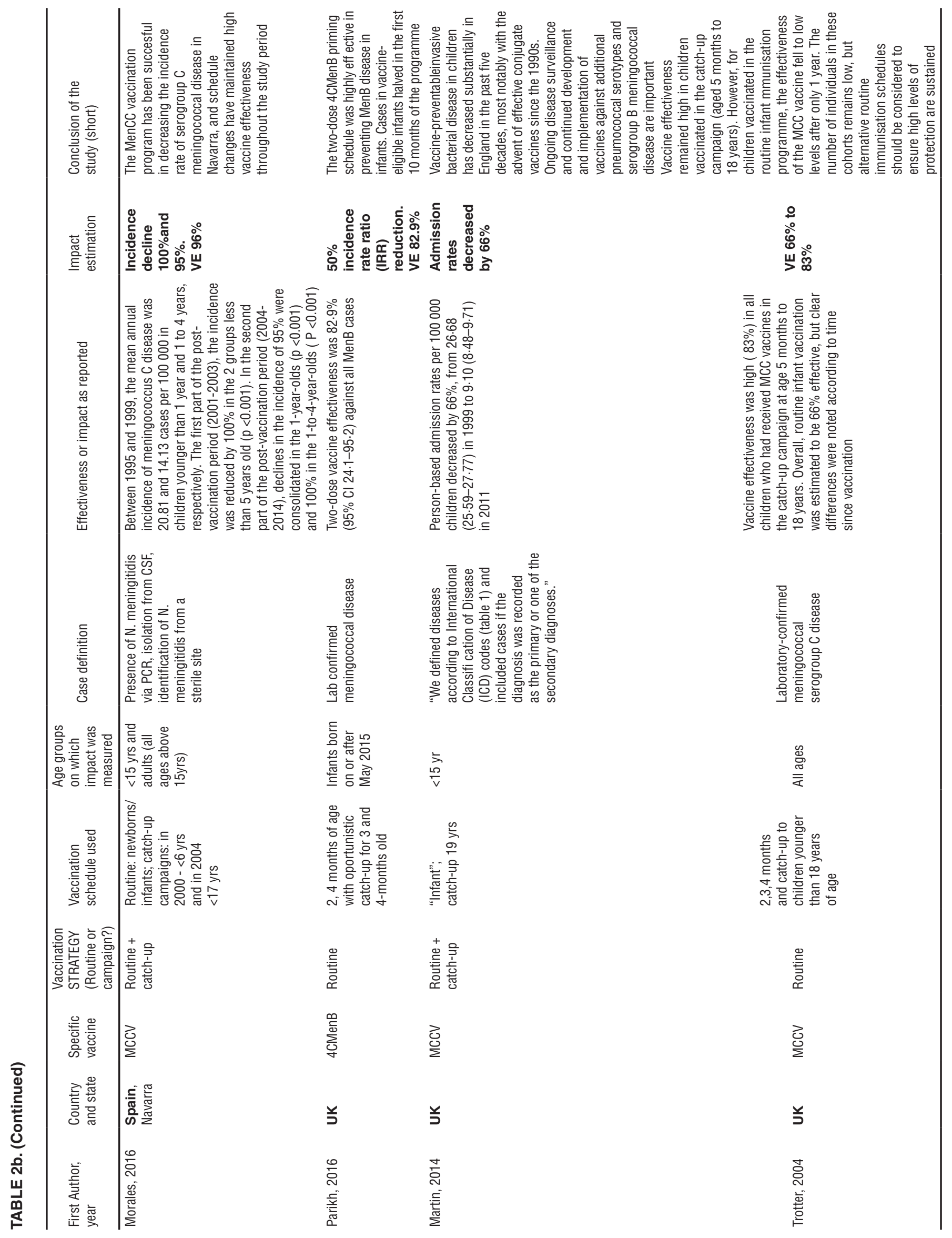




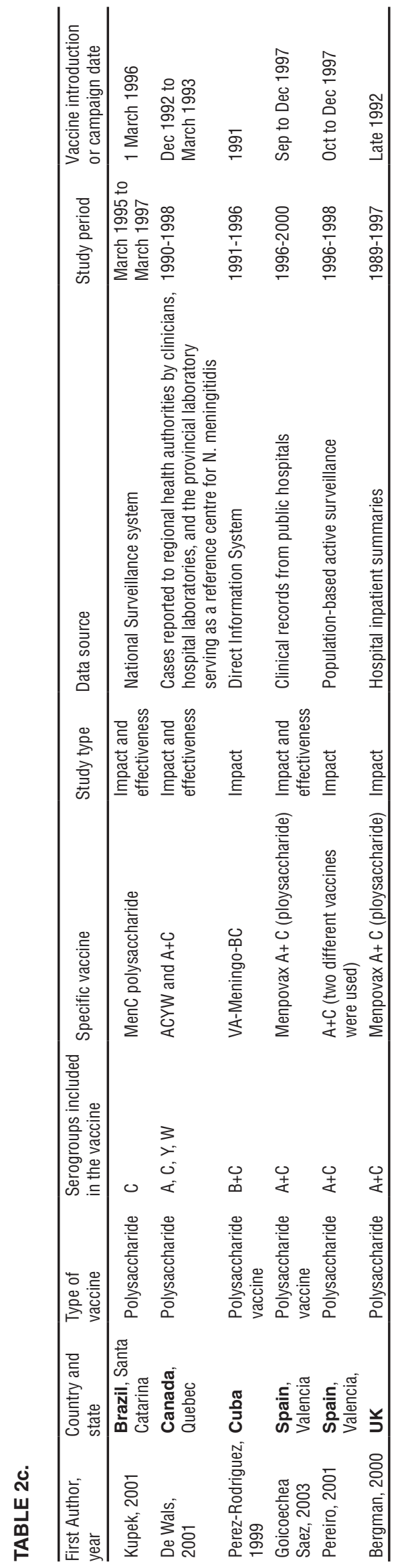




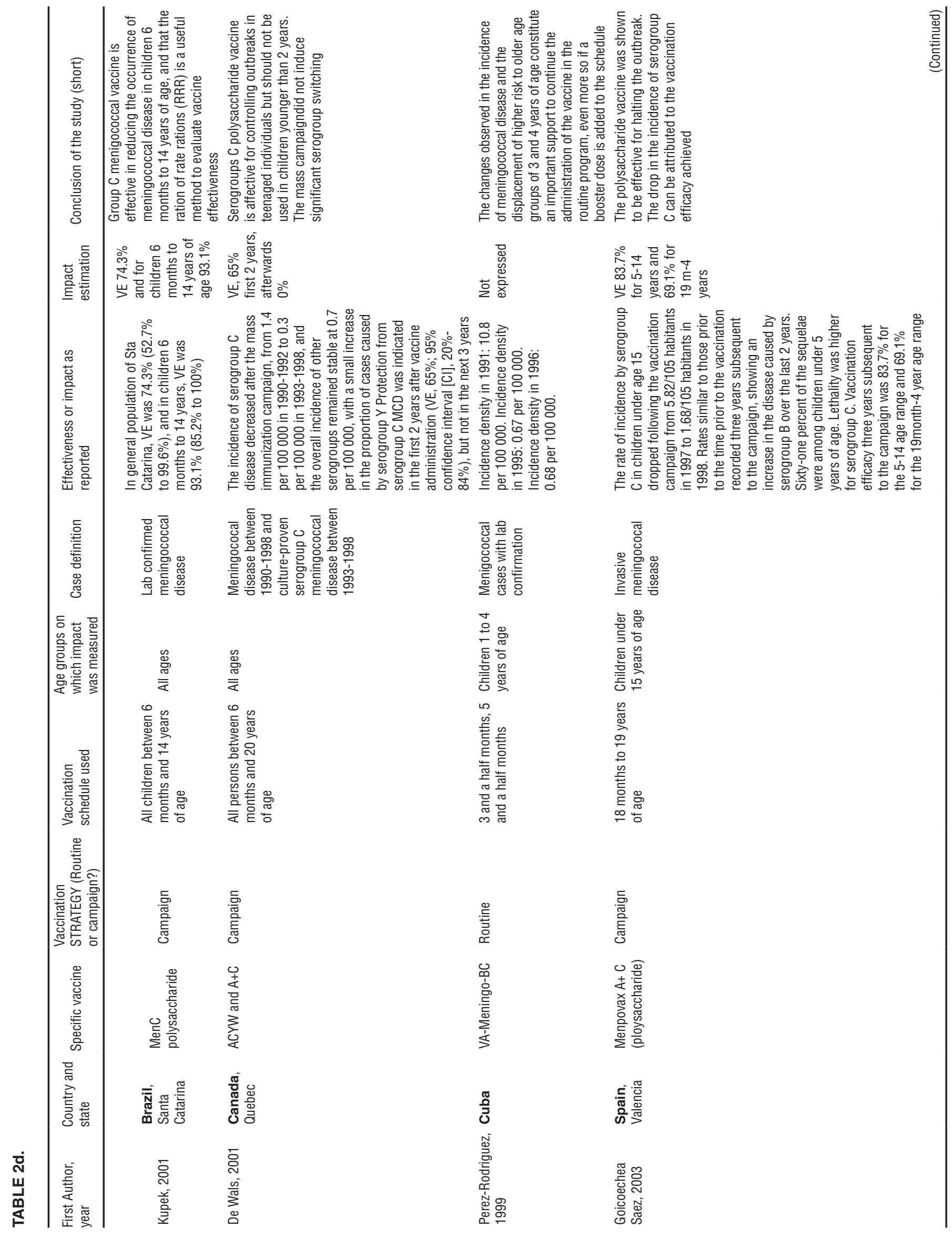




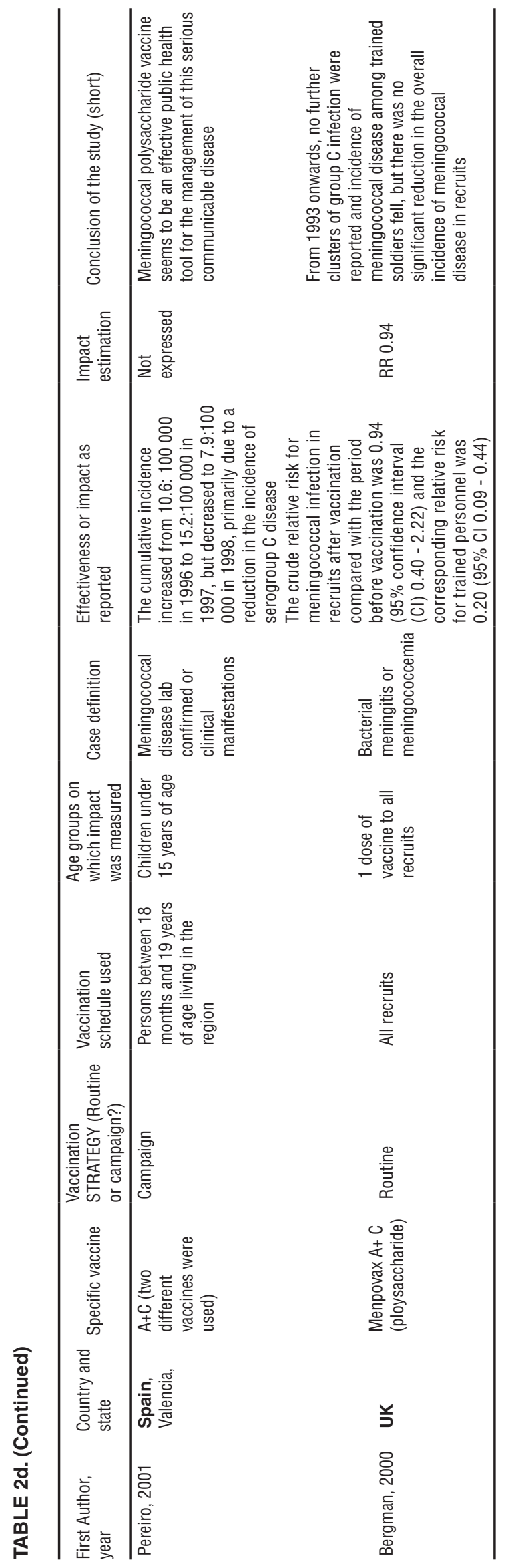


Only four of the studies selected for this review originated in Latin America and the Caribbean (LAC). This was not unexpected since only three countries in the area have introduced a meningococcal vaccine into their routine schedule and conducting these types of studies in LAC is challenging due to the area's insufficient surveillance of meningococcal disease. All four studies obtained their disease-burden data from Regional public health laboratories. This reinforces the premise that regional surveillance systems are of paramount importance to estimating the impact of vaccine introduction, and therefore, should be adequately maintained and strengthened (13).

\section{CONCLUSIONS}

These 32 studies have suggested or shown a reduction in cases and deaths due to vaccine-serotype invasive meningococcal disease after introduction of a meningococcal vaccine to the routine schedule or as part of a mass campaign. When considering the meningococcal vaccine, each LAC country should take into account its particular epidemiologic profile, as well as the cost of these vaccines, only one of which-the conjugate tetravalent ACYW-135is currently offered through the PAHO Revolving Fund (US\$20.30 per dose; 47).

\section{REFERENCES}

1. Plotkin S, Orenstein W, Offit P. Vaccines. 6th ed. Paris: Elsevier; 2012.

2. Halperin SA, Bettinger JA, Greenwood B, Harrison LH, Jelfs J, Ladhani SN, et al. The changing and dynamic epidemiology of meningococcal disease. Vaccine. 2012;30 Suppl 2:B26-36.

3. Pelton SI. The global evolution of meningococcal epidemiology following the introduction of meningococcal vaccines. J Adolesc Health. 2016;59(2 Suppl):S3-S11.

4. Baccarini C, Ternouth A, Wieffer H, Vyse A. The changing epidemiology of meningococcal disease in North America, 19452010. Hum Vaccin Immunother. 2013;9(1): 162-71.

5. United States Food and Drug Administration. Vaccines, Blood \& Biologics-Bexsero, 2016. Available from: https://www.fda. gov / BiologicsBloodVaccines / Vaccines / ApprovedProducts/ucm431374.htm Accessed 17 October 2017.

6. European Medicines Agency. Human medicines-Bexsero,2017. Available from: www.ema.europa.eu / ema / index. jsp?curl=pages $/$ medicines $/$ human $/$ medicines / 002333 / human_med_001614. jsp\&mid=WC0b01ac058001d124 Accessed 17 October 2017.

7. World Health Organization. WHO vaccine-preventable diseases: monitoring system. 2016 global summary, 2017. Available from: http://apps.who.int/immunization_monitoring/globalsummary Accessed 17 October 2017.

8. World Health Organization. Immunization, vaccines and biologicals. Data, statistics and graphics. 2017; Available from: www.who. int/immunization/monitoring_surveillance/data/en/ Accessed 17 October 2017.

9. Ruttimann RW, Gentile A, Parra MM, Saez-Llorens X, Safadi MA, Santolaya ME. A consensus statement: meningococcal disease among infants, children and adolescents in Latin America. Pediatr Infect Dis J. 2014;33(3):284-90.
10. Safadi MA, Berezin EN, Oselka GW. A critical appraisal of the recommendations for the use of meningococcal conjugate vaccines. J Pediatr (Rio J). 2012;88(3):195-202.

11. Safadi MA, O'Ryan M, Valenzuela Bravo MT, Brandileone MC, Gorla MC, de Lemos AP, et al. The current situation of meningococcal disease in Latin America and updated Global Meningococcal Initiative (GMI) recommendations. Vaccine. 2015;33(48):6529-36.

12. Lawrence GL, Wang H, Lahra M, Booy R, Mc IP. Meningococcal disease epidemiology in Australia 10 years after implementation of a national conjugate meningococcal C immunization programme. Epidemiol Infect. 2016;144(11):2382-91.

13. Tauil Mde C, Carvalho CS, Vieira AC, Waldman EA. Meningococcal disease before and after the introduction of meningococcal serogroup $C$ conjugate vaccine. Federal District, Brazil. Braz J Infect Dis.

14. Cardoso CW, Pinto LL, Reis MG, Flannery $\mathrm{B}$, Reis JN. Impact of vaccination during an epidemic of serogroup $\mathrm{C}$ meningococcal disease in Salvador, Brazil. Vaccine. 2012;30(37):5541-6.

15. Bettinger JA, Scheifele DW, Le Saux N, Halperin SA, Vaudry W, Tsang R. The impact of childhood meningococcal serogroup $\mathrm{C}$ conjugate vaccine programs in Canada. Pediatr Infect Dis J. 2009;28(3): 220-4. Boulianne N, De Serres G. Effectiveness of serogroup $C$ meningococcal conjugate vaccine: a 7-year follow-up in Quebec, Canada. Pediatr Infect Dis J. 2011;30(7):566-9.

17. Sadarangani M, Scheifele DW, Halperin SA, Vaudry W, Le Saux N, Tsang R, et al. The impact of the meningococcal serogroup $C$ conjugate vaccine in Canada between 2002 and 2012. Clin Infect Dis. 2014;59(9):1208-15.

18. Siu T, Tang W, Dawar M, Patrick DM. Impact of routine immunization using 2014;18(4):379-86.

16. De Wals P, Deceuninck G, Lefebvre B,
LAC countries should also strengthen their epidemiological surveillance systems to include serogroup-specific surveillance of invasive meningococcal disease. Adequate surveillance can measure the magnitude of this public health issue, thereby informing decision makers, while setting an epidemiologic foundation for conducting future vaccine impact and effectiveness studies.

\section{Conflict of interests: None declared.}

Disclaimer. Authors hold sole responsibility for the views expressed in the manuscript, which may not necessarily reflect the opinion or policy of the RPSP/ PAJPH and/or PAHO.

meningococcal C conjugate vaccine on invasive meningococcal disease in British Columbia. Can J Public Health. 2008;99(5): 380-2.

19. Wormsbecker AE, Wong K, Jamieson FB, Crowcroft NS, Deeks SL. Epidemiology of serogroup $\mathrm{C}$ and $\mathrm{Y}$ invasive meningococcal disease (IMD) in Ontario, 2000-2013. Vaccine program impact assessment. Vaccine. 2015;33(42):5678-83.

20. Kinlin LM, Jamieson F, Brown EM, Brown S, Rawte P, Dolman S, et al. Rapid identification of herd effects with the introduction of serogroup $\mathrm{C}$ meningococcal conjugate vaccine in Ontario, Canada, 2000-2006. Vaccine. 2009;27(11):1735-40.

21. De Wals P, Deceuninck G, Boulianne N, De Serres G. Effectiveness of a mass immunization campaign using serogroup C meningococcal conjugate vaccine. JAMA 2004;24;292(20):2491-4

22. Ó Maoldomhnaigh C, Drew RJ, Gavin P, Cafferkey M, Butler KM. Invasive meningococcal disease in children in Ireland, 2001-2011. Arch Dis Child. 2016;101(12): 1125-9.

23. de Waure C, Miglietta A, Nedovic D, Mereu G, Ricciardi W. Reduction in Neisseria meningitidis infection in Italy after Meningococcal C conjugate vaccine introduction: A time trend analysis of 19942012 series. Hum Vaccin Immunother. 2016;12(2):467-73.

24. Pascucci MG, Di Gregori V, Frasca G, Rucci P, Finarelli AC, Moschella L, et al. Impact of meningococcal $C$ conjugate vaccination campaign in Emilia-Romagna, Italy. Hum Vaccin Immunother. 2014;10(3): 671-6.

25. Bechini A, Levi M, Boccalini S, Tiscione E, Balocchini E, Canessa C, et al. Impact on disease incidence of a routine universal and catch-up vaccination strategy against Neisseria meningitidis C in Tuscany, Italy. Vaccine. 2012;30(45):6396-401.

26. Mooney JD, Christie P, Robertson C, Clarke SC. The impact of meningococcal 
serogroup C conjugate vaccine in Scotland. Clin Infect Dis. 2004;39(3):349-56.

27. Cano R, Larrauri A, Mateo S, Alcala B, Salcedo C, Vazquez JA. Impact of the meningococcal C conjugate vaccine in Spain: an epidemiological and microbiological decision. Euro Surveill. 2004;9(7):11-5.

28. Garrido-Estepa M, Leon-Gomez I, Herruzo R, Cano R. Changes in meningococcal $C$ epidemiology and vaccine effectiveness after vaccine introduction and schedule modification. Vaccine. 2014;32(22):2604-9.

29. Larrauri A, Cano R, Garcia M, Mateo S. Impact and effectiveness of meningococcal $\mathrm{C}$ conjugate vaccine following its introduction in Spain. Vaccine. 2005;23(32):4097-100.

30. Salleras L, Dominguez A, Cardenosa N. Impact of mass vaccination with polysaccharide conjugate vaccine against serogroup $\mathrm{C}$ meningococcal disease in Spain. Vaccine. 2003;21(7-8):725-8.

31. Cruz Rojo C, Garcia Gil C, Nieto Vera J, Monroy Morcillo A. Impact of systematic vaccination with the antimeningococcal $\mathrm{C}$ conjugated vaccine in a health area in Andalusia. Rev Esp Salud Publica. 2005;79(6):655-63.

32. Salleras L, Dominguez A, Cardenosa N. Dramatic decline of serogroup $C$ meningococcal disease in Catalonia (Spain) after a mass vaccination campaign with meningococcal C conjugated vaccine. Vaccine. 2003;21(7-8):729-33.

33. Rego Romero E, Nartallo Penas V, Taboada Rodriguez JA, Malvar Pintos A, Hervada Vidal X, Lopez Pimentel MJ. Implementation and impact of a meningococcal $\mathrm{C}$ conjugate vaccination program in 13- to 25-year-old individuals in Galicia, Spain. Z Gesundh Wiss. 2011;19(5):409-15.

34. Morales D, Garcia-Cenoz M, Moreno L, Bernaola E, Barricarte A, Castilla J. Meningococcal $C$ conjugate vaccine: Impact of a vaccination program and long-term effectiveness in Navarra, Spain, 2000-2014.
Enferm Infecc Microbiol Clin. 2016;34(10): 639-44.

35. Parikh SR, Andrews NJ, Beebeejaun K, Campbell H, Ribeiro S, Ward C, et al. Effectiveness and impact of a reduced infant schedule of $4 \mathrm{CMenB}$ vaccine against group B meningococcal disease in England: a national observational cohort study. Lancet. 2016;388(10061):2775-82.

36. Martin NG, Sadarangani M, Pollard AJ, Goldacre MJ. Hospital admission rates for meningitis and septicaemia caused by Haemophilus influenzae, Neisseria meningitidis, and Streptococcus pneumoniae in children in England over five decades: a population-based observational study. Lancet Infect Dis. 2014;14(5):397-405.

37. Trotter CL, Andrews NJ, Kaczmarski EB, Miller E, Ramsay ME. Effectiveness of meningococcal serogroup $C$ conjugate vaccine 4 years after introduction. Lancet. 2004;364(9431):365-7.

38. Kupek E, Puricelli RC, Westrupp MH. Effectiveness of a mass immunization campaign against serogroup $\mathrm{C}$ meningococci in children in the federal state of Santa Catarina, Brazil. Braz J Infect Dis. 2001;5(6):324-31.

39. De Wals P, De Serres G, Niyonsenga T. Effectiveness of a mass immunization campaign against serogroup $\mathrm{C}$ meningococcal disease in Quebec. JAMA. 2001; 285(2):177-81.

40. Perez Rodriguez A, Meneses FO. VA-MENGOC-BC vaccine: its impact on meningococcal disease in children 1-4 years old. Rev Cubana Med Trop. 1999; 51(3):189-93.

41. Goicoechea Saez M, Fullana Montoro AM, Momparler Carrasco P, Redondo Gallego MJ, Brines Solanes J, Bueno Canigral FJ. Evolution of meningococcal infection among infant population in the autonomous community of Valencia (1996-2000). Effectiveness of $\mathrm{A}+\mathrm{C}$ meningococcal vaccination. Rev Esp Salud Publica. 2003;77(1):125-42.

42. Pereiro I, Diez-Domingo J, Morant A, Gimeno C, Lerma M, San-Martin M, et al. Epidemiological pattern of meningococcal disease in Valencia, Spain. Impact of a mass immunization campaign with meningococcal $C$ polysaccharide vaccine. Scand J Infect Dis. 2001;33(8):581-4.

43. Bergman BP, Hayton JC, Green AD. Effectiveness of the meningococcal vaccination programme for British Armed Forces recruits. Commun Dis Public Health. 2000;3(4):298-9.

44. Khatami A, Pollard AJ. The epidemiology of meningococcal disease and the impact of vaccines. Expert Rev Vaccines. 2010;9(3):285-98.

45. Hanquet G, Valenciano M, Simondon F, Moren A. Vaccine effects and impact of vaccination programmes in post-licensure studies. Vaccine. 2013;31(48):5634-42.

46. GOV.UK. Correspondence. MenB vaccination: introduction from September 2015 Available from: https://www.gov.uk/ government/publications/menb-vaccination-introduction-from-1-september-2015 Accessed 17 October 2017.

47. Pan American Health Organization Revolving Fund Prices, 2017. Available from: http://www2.paho.org/hq/ index.php?option=com_content\&view= article\&id $=9561 \% 3 \mathrm{~A} 2014$-revolving-fund - prices\&catid $=839 \% 3$ Arevolving-fund \& Itemid $=40714 \&$ lang $=$ en Accessed 17 October 2017.

Manuscript received on 2 May 2017. Accepted for publication on 11 August 2017. 
RESUMEN

Examen del impacto y la efectividad de las vacunas antimeningocócicas

Palabras clave
Objetivos. Resumir y evaluar críticamente los datos científicos sobre la repercusión y la eficacia de los programas de vacunación antimeningocócica en todo el mundo para orientar la toma de decisiones en América Latina y el Caribe.

Métodos. Se realizó un examen de la bibliografía siguiendo varios componentes de las directrices correspondientes a los elementos de notificación preferidos para revisiones sistemáticas y metanálisis. Se hicieron búsquedas en PubMed Central ${ }^{\circledR}$ para encontrar documentos publicados en cualquier idioma desde enero de 1999 hasta marzo del 2017.

Resultados. En total, se incluyeron 32 estudios, en cuya mayoría se evaluaba la vacuna antimeningocócica conjugada contra el serotipo C. En 14 estudios se midió la efectividad y en 30, el impacto. La efectividad de las vacunas polisacarídeas se encontraba entre $65 \%$ y $83,7 \%$ (grupos etarios diferentes), mientras que la de las vacunas conjugadas, entre $66 \%$ y $100 \%$. Gracias a la vacuna conjugada, la disminución de la incidencia de la enfermedad meningocócica confirmada en laboratorio varió entre $77 \%$ y $100 \%$ en diferentes grupos etarios. En el único estudio en el que se evaluó la vacuna de subunidades proteínicas se notificó que su efectividad era de 82,9\%.

Conclusiones. Los estudios examinados muestran el impacto y la efectividad tanto de las vacunas polisacarídeas como de las vacunas conjugadas en relación con la enfermedad meningocócica causada por los serotipos utilizados en las vacunas. Sin embargo, las vacunas conjugadas demuestran que tienen un mayor impacto y efectividad que las vacunas polisacarídeas para dar una protección más duradera. En vista de la varianza del posible uso de una vacuna antimeningocócica, se deben fortalecer los sistemas de vigilancia epidemiológica para orientar las decisiones nacionales.

Vacunas meningococicas; programas de inmunización; toma de decisiones, prevención \& control; revision; América Latina.
RESUMO

\section{Impacto e efetividade das vacinas meningocócicas: uma revisão sistemática}

Objetivos. Sumarizar e analisar de maneira crítica as evidências sobre o impacto e a efetividade dos programas de vacinação contra doença meningocócica em todo o mundo para subsidiar a tomada de decisão na América Latina e no Caribe.

Métodos. Uma revisão da literatura científica foi realizada de acordo com vários componentes das diretrizes dos Principais itens para relatar revisões sistemáticas e meta-análises (PRISMA). Foi feita uma pesquisa da base de dados PubMed Central ${ }^{\circledR}$ em busca de estudos publicados em qualquer idioma de janeiro de 1999 a março de 2017.

Resultados. Trinta e dois estudos foram selecionados, sendo que a maioria avaliou a vacina conjugada contra o meningococo C. Quatorze artigos avaliaram a efetividade da vacina e 30, o impacto. A efetividade das vacinas polissacarídicas foi de $65 \%$ a $83,7 \%$ (em diferentes faixas etárias) e a das vacinas conjugadas foi de $66 \%$ a $100 \%$. A redução com o uso da vacina conjugada da incidência de doença meningocócica confirmada por laboratório variou de $77 \%$ a $100 \%$ em diferentes faixas etárias. O único estudo que avaliou a vacina de subunidade proteica informou uma efetividade de $82,9 \%$.

Conclusões. Os estudos examinados indicam impacto e efetividade da vacina polissacarídica e da vacina conjugada para doença meningocócica do respectivo sorogrupo vacinal. As vacinas conjugadas demonstram maior impacto e efetividade e proteção mais duradoura em relação às vacinas polissacarídicas. Diante da variação do uso em potencial da vacina meningocócica, os sistemas de vigilância epidemiológica devem ser reforçados visando subsidiar a tomada de decisão das autoridades nacionais.

Palavras-chave Vacinas meningocócicas; programas de imunização; tomada de decisões, prevenção \& controle; revisão; América Latina. 